\title{
Penguatan Pengetahuan Menjaga Tubuh Tetap Sehat Dengan Gizi Seimbang Menyambut Masa New Normal
}

Strengthening of Knowledge Keeps the Body Stay Healthy with Balanced Nutrition Facing the New Normal Era

\author{
Amalia Rahma ${ }^{1 *}$, Dwi Novri Supriatiningrum ${ }^{1}$ \\ ${ }^{1}$ Fakultas Kesehatan, Universitas Muhammadiyah Gresik \\ *dwinovri@umg.ac.id
}

\begin{abstract}
ABSTRAK
Kegiatan pengabdian masyarakat ini sebagai salah satu edukasi ke masyarakat untuk meningkatkan dan mempertahankan kondisi kesehatan dalam menyambut masa new normal. Kegiatan ini dilakukan melalui online, dikirimkan dengan grup maupun tersebar ke perseorangan yang berdomisili di wilayah Surabaya. Responden dari golongan usia anak sekolah, remaja, dan dewasa karena diprioritaskan pada individu yang memiliki gadget dan dapat mengoperasikan secara mandiri. Metode: Edukasi dilakukan melalui membagi video dan booklet terkait gizi seimbang memuat tentang definisi gizi seimbang, penerapan konsumsi sesuai gizi seimbang, variasi zat gizi yang dikonsumsi, membatasi konsumsi minyak, gula, dan garam, mengkonsumsi air yang cukup, melakukan perilaku hidup bersih dan sehat, gizi seimbang mendukung kesehatan untuk menjaga imunitas. Kegiatan ini dilaksanakan bulan Juni 2020 melalui grup dan chat personal media sosial warga di Surabaya Selatan. Hasil: Responden menjaga kodisi tubuh agar tetap sehat dengan pola gizi seimbang, pola hidup bersih dan sehat. Pemantauan selanjutnya dilakukan melalui pemeriksaan kesehatan saat berkunjung di beberapa responden. Conclusion: responden mendukung untuk melakukan hidup sehat, menerapkan pedoman gizi seimbang untuk menjaga imunitas di masa menjelang new normal.
\end{abstract}

Kata kunci - tetap sehat, gizi seimbang, praktek hidup bersih dan sehat, imunitas

\begin{abstract}
This community service activity is one of the ways to educate the public to improve and maintain health conditions in welcoming the new normal. This activity is carried out online, sent by groups or distributed to individuals in Surabaya. Respondents were from school children, adolescents, and adults because they were prioritized for individuals who had gadgets and could operate independently. Methods: This activity (education) is carried out through share videos and booklets related to balanced nutrition containing the definition of balanced nutrition, application of consumption according to balanced nutrition, variations in nutrients consumed, limiting consumption of oil, sugar and salt, consuming adequate water, carrying out clean and healthy living habits, balanced nutrition support health to maintain immunity. The purpose of this activity is for the community to maintain the body's condition in order to stay healthy with a balanced nutrition pattern, a clean and healthy lifestyle. This activity was carried out in June 2020 through groups and personal social media chat for local residents. Results: Respondents maintain body condition in order to stay healthy with a balanced nutritional pattern, a clean and healthy lifestyle. Further monitoring was carried out through health checks during visits to several respondents. Conclusion: The respondents support them to live a healthy life, apply balanced nutrition guidelines to maintain immunity in the period leading up to the new normal.
\end{abstract}

Keywords - stay healthy, balanced nutrition, clean and healthy life practice, immunity 


\section{Pendahuluan}

Pada bulan Desember 2019 terjadi banyak kasus pneumonia di Tiongkok dan belum diketahui penyebabnya. Dalam 3 hari, pasien dengan kasus virus korona meningkat dan terus bertambah hingga bulan Februari 2020 berjumlah ribuan kasus. Berdasarkan data epidemiologi menunjukkan $66 \%$ pasien berkaitan atau terpajan pada satu pasar seafood atau live market di Wuhan, Tiongkok, China. Sampel isolate diteliti dengan hasil menunjukkan adanya infeksi coronavirus, jenis betacoronavirus tipe baru, diberi nama 2019 novel Coronavirus (2019-nCoV). Pada bulan Februari 2020, World Health Organization memberi nama virus baru tersebut Severa acute respiratory syndrome coronavirus-2 (SARSCoV-2) dan nama penyakitnya sebagai Coronavirus disease 2019/ COVID-19 (Burhan, $[2])$.

Di Indonesia berdasarkan data WHO (2020) pada 18 Mei 2020 mengalami lonjakan jumlah kasus positif virus korona sebanyak 4.757 kasus, peningkatan setiap minggu rata-rata 1275. Di tanggal 30 Mei tercatat positif 25.773 dan sembuh 7.015. Jawa Timur merupakan provinsi dengan jumlah kasus kumulatif kedua tertinggi di Indonesia setelah DKI Jakarta, sejak wilayah itu mengalami lonjakan yang tajam pada akhir bulan Mei. Terutama di Surabaya sejak pertama mulai menerapkan PSBB pada 28 April dan kemudian diperpanjang sebanyak dua kali. Sehingga PSBB fase ketiga akan berakhir pada 8 Juni mendatang. Namun penerapan PSBB dinilai sejak awal tidak berjalan sesuai harapan dan hingga kini, sehingga Surabaya belum bisa dikategorikan aman. Hal ini disebabkan oleh perilaku masyarakat karena pemerintah tidak melakukan kontrol yang ketat (tidak ada pengawasan di jalanan) di Surabaya (Tambunan, [6]).

Berdasarkan data sampai dengan 12 Februari 2020 angka mortalitas di dunia 2,1\%, Indonesia terdapat 55.092 kasus, Jawa Timur dikonfirmasi 11.805 kasus, pasien sembuh 3.891 orang, dan 863 orang. Dari aspek klinik, khususnya penegakan diagnosis, terapi serta pencegahan. Mengingat belum tersedianya vaksin maka perlu untuk memaparkan manfaat sayur, buah, vitamin, paparan sinar ultraviolet, serta makanan dan minuman rempah untuk meningkatkan daya tahan tubuh guna mencegah atau membantu pemulihan dari COVID-19 (Effendi, 2020).

Kejadian luar biasa oleh Coronavirus bukanlah pertama kali terjadi. Di tahun 2002 severe acute respiratory syndrome (SARS) disebabkan oleh SARS-coronavirus (SARS$\mathrm{CoV}$ ) dan penyakit Middle East repiratory syndrome (MERS) tahun 2012 disebabkan oleh MERS-Coronavirus (MERS-CoV) dengan total akumulatif kasus sekitar 10.000 (1000-an kasus MERS dan 8000-an kasus SARS). Mortalitas akibat SARS sekitar 10\% sedangkan MERS terjadi 30\% lebih tinggi (Burhan, [2]).

\section{Target dan Luaran}

Sasaran pengabdian masyarakat ini adalah masyarakat yang memiliki anak balita 6-59 bulan, anak usia sekolah, anak remaja, dan wanita usia subur di desa Petiken Kecamatan Driyorejo Kabupaten Gresik. Kegiatan ini dilakukan untuk mempersiapkan pengetahuan masyarakat dalam menjaga tubuh tetap kondisi sehat dengan gizi seimbang menjelang masa new normal. Masyarakat mendapatkan pengetahuan mengenai Gizi seimbang, pola hidup bersih dan sehat. Pada kegiatan ini diharapkan masyarakat memahami dampak mengaplikasikan pedoman Gizi seimbang dalam mendukung imunitas tetap terjaga. Setelah memahami gizi seimbang dan praktik hidup bersih dan sehat, masyarakat terpandu dalam penerapannya untuk menjaga tubuh tetap sehat di masa menjelang New Normal. Luaran dari kegiatan ini yaitu booklet sebagai pedoman penerapan pola gizi seimbang dan pola hidup bersih dan sehat selama menjelang masa New Normal.

\section{Metodologi}

a. Survei permasalahan pada masyarakat dengan tujuan dan menganalisis sasaran sesuai kegiatan menerapkan perilaku gizi seimbang dalam menjaga imunitas di masa menjelang new normal.

b. Analisis masalah maka disusun media edukasi untuk sosialisasi "Penguatan Pengetahuan Tubuh Tetap Sehat dengan Gizi Seimbang di Masa menjelang New Normal".

c. Penyebaran kuesioner melalui online 
d. Edukasi melalui grup di media sosial dan menyampaikan media edukasi berupa video "Pedoman Gizi Seimbang" dan Booklet "Tubuh Tetap Sehat dengan Gizi Seimbang di Masa menjelang New Normal". Tahap keempat yaitu dilakukan monitoring dan evaluasi mengenai penerapan gizi seimbang dan pola hidup bersih, sehat dalam menjaga imunitas di masa ini.

e. Prosedur penerapan gizi seimbang dan pola hidup bersih, sehat dalam menjaga imunitas.

f. Identifikasi penerapan "Pedoman Gizi Seimbang" dan pola hidup bersih, sehat dalam menjaga imunitas.

\section{Pembahasan}

Pada penerapan pola hidup sehat normal didapatkan hampir seluruh masyarakat perlu menerapkan perilaku hidup sehat. Hal ini dilakukan untuk mengurangi dampak penularan virus korona melalui benda-benda yang dibawa dari luar rumah, maka masyarakat seharusnya mulai terbiasa melakukan protokol kesehatan. Perilaku ini sangat berpengaruh besar terhadap penularan virus korona melalui droplet yang menempel pada benda-benda dan dapat dibersihkan dengan penyemprotan desinfektan atau menggunakan hand sanitizier, dan cuci tangan.

Enam tips praktek hidup sehat dengan gizi seimbang sangat berperan dalam proses tebentuknya imunitas tubuh dalam melawan virus korona. Enam tips tersebut yaitu, jaga pola makan yang cukup, beragam dan seimbang, perbanyak konsumsi buah dan sayur, jaga kesehatan usus, hindari kontaminasi kuman melalui makanan, tetap aktif bergerak serta menghindari stress, dan mempraktekkan hidup bersih.

Table 1. Kuesioner Pedoman Gizi Seimbang

\begin{tabular}{|c|c|c|c|c|c|}
\hline \multirow{2}{*}{ No. } & \multirow{2}{*}{ Pernyataan } & \multicolumn{4}{|c|}{ Jawaban } \\
\hline & & SS & $\mathbf{S}$ & TS & STS \\
\hline 1 & $\begin{array}{l}\text { Konsumsi makanan dengan prinsip cukup dan beranekaragam untuk menjaga } \\
\text { immunitas }\end{array}$ & $50 \%$ & $46,9 \%$ & $3,1 \%$ & $0 \%$ \\
\hline 2 & $\begin{array}{l}\text { Konsumsi sumber karbohidrat, protein hewani, protein nabati, sayuran, buah, } \\
\text { dan batasi penggunaan minyak, gula, serta garam. }\end{array}$ & $46,9 \%$ & $46,9 \%$ & $6,2 \%$ & $0 \%$ \\
\hline 3 & $\begin{array}{l}\text { Tercukupi kebutuhan zat gizi dalam sehari dapat dilengkapi dengan } \\
\text { memperbanyak konsumsi sayur }\end{array}$ & $62,5 \%$ & $34,4 \%$ & $3,1 \%$ & $0 \%$ \\
\hline 4 & $\begin{array}{l}\text { Tercukupi kebutuhan zat gizi dalam sehari dapat dilengkapi dengan } \\
\text { memperbanyak konsumsi buah }\end{array}$ & $50 \%$ & $50 \%$ & $0 \%$ & $0 \%$ \\
\hline 5 & Menjaga kesehatan usus sama halnya menjaga imunitas kita & $31,2 \%$ & $68,8 \%$ & $0 \%$ & $0 \%$ \\
\hline 6 & $\begin{array}{l}\text { Mengolah makanan sebelum dikonsumsi merupakan hal penting untuk } \\
\text { beberapa jenis makanan seperti makanan pokok, lauk nabati, lauk hewani, } \\
\text { dan sayuran. }\end{array}$ & $56,2 \%$ & $43,8 \%$ & $0 \%$ & $0 \%$ \\
\hline 7 & Memilih makanan yang Halal dan Thoyyib & $62,5 \%$ & $37,5 \%$ & $0 \%$ & $0 \%$ \\
\hline 8 & $\begin{array}{l}\text { Kegiatan olahraga untuk menjaga tubuh tetap sehat di masa menjelang New } \\
\text { Normal dalam waktu }\end{array}$ & $68,8 \%$ & $31,2 \%$ & $0 \%$ & $0 \%$ \\
\hline
\end{tabular}

Dari keenam tips ini sebagian telah menjalankan enam tips praktek hidup sehat dengan gizi seimbang. Dengan dalam jumlah besar yaitu praktek hidup bersih dan dalam jumlah terendah masyarakat belum melakukan hidup sehat dengan menjaga kesehatan usus.
Sebagian masyarakat peduli terhadap imunitas dengan mengkonsumsi makanan yang cukup dan beranekaragam untuk menjaga imunitas dengan mengkonsumsi cukup dan beranekaragam makanan. Kemudian adanya sikap konsumsi sumber karbohidrat, protein hewani, protein nabati, sayuran, buah dan 
membatasi penggunaan minyak, gula, dan garam. Makanan yang mengandung zat gizi seharusnya dikonsumsi dengan cukup dan bervariasi pada menu setiap harinya. Aplikatif di masyarakat dari prinsip gizi seimbang antara lain, mengkonsumsi sesuai kebutuhan individu, responden mengkonsumsi makanan dalam satu sajian terdiri beraneka ragam makanan (terdapat makanan pokok, lauk hewani dan nabati, sayur dan buah), mengkonsumsi makanan dalam porsi kecil, menggunakan proporsi seporsi dalam sekali makan yaitu 1/3 untuk sayur, 1/6 untuk lauk pauk dan 1/6 untuk buah (seperti dalam piring makanku). Namun belum banyak melakukan sharing dengan anggota keluarga lain untuk makanan dalam porsi besar. Semakin beragam jenis pangan yang dikonsumsi semakin mudah untuk memenuhi kebutuhan gizi. Bahkan semakin beragam pangan yang dikonsumsi semakin mudah tubuh memperoleh berbagai zat lainnya yang bermanfaat bagi kesehatan (Kemenkes, [5]).

Menjaga kesehatan usus sama halnya menjaga imunitas seseorang. Dinyatakan bahwa $68,8 \%$ responden setuju dan $31,3 \%$ responden sangat setuju bahwa kondisi usus adalah hal penting yang berpengaruh pada imunitas seseorang. Apabila gastrointestinal mengalami gangguan akibat penyakit, terapi diet sering diperlukan untuk memberikan nutrient mudah dicerna serta mudah diserap sehingga menghindari malabsorpsi (Beck, 2011 [2]).

Dalam memprioritaskan kesehatan usus maka dapat dilakukan dengan mengkonsumsi serat yang cukup, minum air yang cukup, dan mengkonsumsi pangan sumber prebiotik dan probiotik. Dinyatakan bahwa sebagian masyarakat sependapat dan mencoba untuk mengaplikasikan dalam kehidupan sehari-hari. Diet yang paling sering digunakan untuk gangguan saluran pencernaan adalah diet tinggi serat. Peningkatan kandungan serat makanan merupakan tindakan yang paling berhasil dalam mengatasi gangguan saluran penceraan (Beck, 2011 [2])

Cara lain dalam menjaga kesehatan usus yaitu dengan mengolah makanan sesuai jenis bahan makanan yang diolah selain itu untuk memudahkan sistem pencernaan dalam mencerna serta mendapatkan makanan yang aman dari mikroorganisme parasit. Beck, 2011
Makanan diperlukan tubuh untuk hidup, tetapi dapat mengakibatkan sakit bila mengandung bakteri atau parasit berbahaya, atau mengandung bahan-bahan kimia beracun. Pengawasan dengan cermat diperlukan dalam semua tahapan pengolahan makanan untuk menjamin bahwa makanan tersebut tidak tercemar dan tidak mengakibatkan sakit.

Beck, 2011 [2] Menyatakan bahwa memasak dengan pemakaian panas membuat sejumlah besar makanan memiliki citarasa yang lebih dapat diterima dan menimbulkan selera serta lebih mudah dan lebih aman dikonsumsi. Memasak merupakan tindakan baik tetapi nilainilai gizi pada makanan kadang-kadang berubah akibat proses pemasakan. Beberapa tips memasak sehat telah dilakukan responden demi mendapatkan makanan dengan gizi seimbang, bersih, dan sehat sehingga dapat menjaga imunitas di masa new normal. Prevalensi tips memasak yang dilakukan di masyarakat antara lain paling banyak pertama yaitu menggunakan bahan alami sebagai penyedap masakan seperti rempah-rempah, perasan jeruk nipis, dan lainlain; kedua, menghidangkan masakan dari sumber karbohidrat, protein, lemak, sayuran; ketiga, menghindari memasak dengan penggunaan minyak banyak; keempat, memasak hidangan yang mudah dan dikuasai (memahami karakteristik bahan dan cara pengolahannya); kelima, hidangan makanan dimasakan dengan cara : kukus, tumis, panggang dengan oven atau direbus; dan keenam, menggunakan komposisi makanan sehat seperti sedikit gula, garam, dan minyak, hindari penggunaan santan, penyedap rasa, dan lemak hewan.

Pemilihan makanan baik dan sehat dengan makanan dijamin kehalalannya termasuk cara untuk menjaga kesehatan. Setiap manusia apapun agama dan keyakinan yang dianutnya, pasti memerlukan makanan untuk kelangsungan hidupnya. Dan agar selamat dalam kehidupannya secara fisik-biologis, sehat secara fisik-jasmani, makanan yang dikonsumsi haruslah halal dan thoyyib, karena semua yang halal itu akan mendatangkan kebaikan dan kemaslahatan (Hasan, [4]).

Praktek hidup bersih dan sehat sangat penting untuk diterapkan dalam menjaga kesehatan dalam menghadapi masa New Normal. Masyarakat melakukan hidup bersih dan sehat 
dalam mempersiapkan menjalani masa New Normal. Kegiatan hidup bersih dan sehat telah dilakukan yaitu, penggunaan masker, mencuci tangan dengan benar, menjaga jarak saat berinteraksi dengan orang lain, membersihkan rumah secara rutin, menyegerakan untuk membersihkan diri dan berganti pakaian setelah keluar rumah, dan menyemprotkan desinfektan pada barang-barang yang diperoleh atau dibawa dari luar rumah. Cuci tangan secara baik dan benar memakai sabun dengan air bersih mengalir adalah agar kebersihan terjaga secara keseluruhan serta mencegah kuman dan bakteri berpindah dari tangan ke makanan yang akan dikonsumsi dan juga agar tubuh tidak terkena kuman. Perilaku hidup bersih harus dilakukan atas dasar kesadaran oleh setiap anggota keluarga agar terhindar dari penyakit, karena 45\% penyakit diare bisa dicegah dengan mencuci tangan (Kemenkes, [5]).

Kegiatan dalam mendukung praktek hidup tetap sehat dengan melakukan olahraga di masa menjelang New Normal. Sebagian besar masyarakat melakukan olahraga minimal seminggu sekali, dan sedikit masyarakat tidak melakukan olahraga sama sekali. aktivitas fisik juga memperlancar sistem metabolisme di dalam tubuh termasuk metabolisme zat gizi. Terjadinya pandemi COVID-19 membuat semua kegiatan harus dilakukan di rumah. Hal ini dapat meningkatkan kejadian stress, berikut merupakan kemungkinan seseorang terhindar dari stress yaitu tidur cukup, dapat mengendalikan ketika muncul emosi atau marah, menghindari rokok, dan memperbanyak beribadah dan berdoa. Berikut hasil pemantauan setelah dilakukan edukasi terkait praktek hidup sehat dengan memperbanyak ibadah dan doa, menghindari rokok, mengendalikan emosi atau marah, dan istirahat cukup.

Setelah kegiatan edukasi dan pemantauan pada masyarakat Surabaya, kemudian dilakukan observasi terhadap masyarakat yang menjadi responden diperoleh perilaku hidup sehat di masa menyambut New Normal anatara lain penerapan hidup sehat di masa menjelang New Normal, penerapan praktek hidup sehat dalam kehidupan sehari-hari, konsumsi makanan dengan prinsip cukup dan beraneka ragam untuk menjaga imunitas, anjuran mengkonsumsi berbagai sumber zat gizi dan membatasi konsumsi minyak, gula, dan garam, penerapan konsumsi sayuran untuk memaksimalkan pencapaian kebutuhan zat gizi dalam sehari, penerapan menjaga kesehatan usus untuk menjaga imunitas, perilaku selektif terhadap makanan untuk menjaga kesehatan tubuh, penerapan mengkonsumsi makanan olahan untuk memudahkan pencernaan dan makanan yang aman dari kontaminasi mikroorganisme parasit konsumsi makanan yang terjamin kehalalannya, penerapan hidup bersih dan sehat sangat penting untuk diterapkan dalam menjaga kesehatan menghadapi masa New Normal, rutinitas olahraga, rutinitas selama berada di rumah, dan membiasakan hidup bersih dan sehat dalam menyambut masa New Normal.

Table 2. Praktek Hidup Bersih Sehat

\begin{tabular}{|c|c|c|c|}
\hline No. & Pernyataan & Ya & Tidak \\
\hline 1 & $\begin{array}{l}\text { Menjaga pola makan } \\
\text { Responden }\end{array}$ & $78,1 \%$ & $21,9 \%$ \\
\hline 2 & $\begin{array}{l}\text { Memperbanyak konsumsi } \\
\text { sayur dan buah }\end{array}$ & $68,8 \%$ & $31,4 \%$ \\
\hline 3 & Menjaga kesehatan usus & $37,5 \%$ & $62,5 \%$ \\
\hline 4 & $\begin{array}{l}\text { Menghindari kontaminasi } \\
\text { kuman dari makanan dengan } \\
\text { memilih, memasak dan } \\
\text { menyimpan makanan dengan } \\
\text { benar, Praktek hidup bersih }\end{array}$ & $68,8 \%$ & $31,2 \%$ \\
\hline 5 & Menghindari stres & $62,5 \%$ & $37,5 \%$ \\
\hline 6 & Praktek hidup bersih dan sehat & $81,3 \%$ & $18,7 \%$ \\
\hline
\end{tabular}

Melalui konsumsi makanan yang beranekaragam seperti sumber karbohidrat, lauk hewani, lauk nabati, sayur, buah, dan asupan air yang cukup. Hal ini bertujuan mendapatkan zat gizi pada makanan dan dapat digunakan tubuh untuk meningkatkan imunitas umumnya dengan memberikan nutrient yang dapat meningkatkan produksi antibodi seperti, protein dengan nilai aktivitas biologis tinggi yakni telur, susu, dan ikan. Susu dan telur diketahui mengandung vitamin D3 dan substansi lainnya yang dapat meningkatkan pembentukkan sel-sel yang terlibatdalam sistem imun tubuh. Telur dan ikan juga mengandung omega-3 sehingga dapat bermanfaat untuk meningkatkan daya tahan tubuh (Effendi, [3]). Dalam waktu yang lama, peningkatan konsumsi buah-buahan dan sayuran 
dianggap penting dalam melindungi manusia terhadap sejumlah penyakit, seperti kanker, diabetes, penyakt neurodegenerative, dan penyakit pembuluh darah jantung dan otak. Saat ini diperkirakan bahwa sifat protektif dari makanan ini dihasilkan dari keberadaanan tioksidan molekul rendah yang melindungi sel dan strukturnya terhadap kerusakan oksidatif. Dugaan efek mengurangi resiko banyak penyakit tidak hanya karena efek antioksidan individu, seperti $\alpha$-tokoferol, asam askorbat, atau $\beta$ karoten tetapi juga mungkin merupakan hasil dari senyawa antioksidan yang belum diketahui atau sinergisitas dari beberapa antioksidan yang hadir bervariasi dalam buah dan sayuran.

Enam tips praktek hidup sehat dengan prevalensi lebih dari setengah jumlah responden yaitu, tetap aktif bergerak serta menghindari stress dan mempraktekkan hidup bersih. Oleh karenanya, aktivitas fisik berperan dalam menyeimbangkan zat gizi yang keluar dari dan yang masuk ke dalam tubuh (Kemenkes, [5]).

\section{Kesimpulan}

Simpulan menyajikan ringkasan dari uraian hasil dan pembahasan, mengacu pada permasalahan mitra. Berdasarkan kedua hal tersebut, uraikan faktor pendukung dan penghambat kegiatan. Kegiatan pengabdian masyarakat dengan edukasi tentang penerapan gizi seimbang, hidup bersih dan sehat untuk tetap sehat di masa menjelang new normal menunjukkan hasil yang positif bahwa penerapan gizi seimbang, hidup bersih dan sehat dapat mempertahankan kondisi tetap sehat di masa new normal. Sebagian responden telah menerapkan konsumsi sayur dan buah, namun ada beberapa responden tidak setuju untuk mengonsumsi sayur untuk menjaga tubuh tetap sehat. Penerapan hidup sehat hampir semua responden telah menyatakan setuju untuk melakukan cuci tangan dengan baik dan menggunakan sabun, menggunakan masker saat berada di luar rumah, segera membersihkan rumah secara rutin, dan menyegerakan untuk membersihkan diri dan berganti pakaian setelah keluar rumah.

Dalam kondisi new normal, banyak perlu pembiasaan kesehatan untuk menjaga tubuh tetap sehat terutama dengan gizi seimbang dan praktek hidup bersih dan sehat. Hal ini perlu ada kader untuk pelaksanaan secara optimal, khususnya pada beberapa poin yang perlu ditingkatkan terkait dengan gizi seimbang yaitu membatasi konsumsi gula, garam, dan minyak, meningkatkan konsumsi sayur dan buah. Sedangkan penerapan hidup bersih dan sehat perlu ditingkatkan yaitu melakukan olahraga secara rutin.

\section{Ucapan Terima Kasih}

Kegiatan ini didanai oleh LPPM Universitas Muhammadiyah Gresik.

\section{Daftar Pustaka}

[1] Badan Pusat Statistik. 2020. Hasil Survei Sosial Demografi Dampak COVID-19. Jakarta: BPS RI

[2] Beck, Mary. Ilmu Gizi dan Diet (Hubungannya dengan penyakit-penyakit untuk Perawat dan Dokter). Yogyakarta: ANDI

[3] Burhan, Erlina. 2020. Pneumonia Covid-19: Diagnosis dan Penatalaksanaan Di Indonesia. Jakarta: Perhimpunan Dokter Paru Indonesia

[4] Effendi, Adi. Dewi, Mira. 2020. Mengenal COVID19 (Corona Virus Disease-2019). Bogor: IPB Press

[5] Hasan, Sofyan. 2014. Kepastian Hukum Sertifikasi dan Labelisasi Halal Produk Pangan. Palembang: Jurnal Dinamika Hukum, Vol. 14 No.2 Mei 2014.

[6] Kemenkes RI. 2020. Situasi Coronavirus Disease 2019 (COVID-19). Surabaya: Dinas Kesehatan Provinsi Jakarta

[7] Tambunan, Liza. 2020. Covid-19 di Surabaya masuk kategori 'Zona Hitam', perilaku warga seperti tidak ada PSBB. Jakarta: https:///www.bbc.com/indonesia/indonesia52905012 (diakses tanggal 4 Juni 2020)

[8] USA: Journal of operation management. Vol.27. 390404. 2009

[9] Nursalam. (2015). Manajemen Keperawatan Aplikasi dalam Praktik Keperawatan Profesional(Ed. 5). Jakarta: Salemba Medika.

[10] RS Arifin Nu'mang. (2017). Profil rumah sakit Arifin Nu'mang Kabuaten Sidenreng Rappang tahun 2017. Rappang, Indonesia. 